\title{
DOKTRYNY KONSERWATORSKIE, A PANEUROPEJSKA IDEA NOWEGO EUROPEJSKIEGO BAUHAUSU I EUROPEJSKIEGO ZIELONEGO ŁADU
}

\section{WŁODARCZYK Marcin ${ }^{1}$ WŁODARCZYK Małgorzata ${ }^{2}$}

${ }^{1}$ dr inż. arch. Marcin Włodarczyk, Wyższa Szkoła Techniczna w Katowicach, Wydział Architektury Budownictwa i Sztuk Stosowanych https://orcid.org/0000-0002-3959-3371

2 dr hab. inż. arch. Małgorzata Włodarczyk, Włodarczyk + Włodarczyk Architekci https://orcid.org/0000-0001-9474-5836

ABSTRAKT: Współcześnie dominuje ekonomia i globalna gospodarka oraz sprawy kryzysu energetycznego i klimatycznego. Sprawy dziedzictwa kulturowego odeszły na plan dalszy. Przykładem mnogość deklaracji i konferencji versus NextGenerationUE, Zielony Ład, Fala Rewaloryzacji i Nowy Bauhaus.

SŁOWA KLUCZE: doktryny konserwatorskie, Baukultur, Nowy Europejski Bauhaus, Europejski Zielony Ład, Europejska Fala Renowacji 


\section{Wstęp}

Współczesny świat doby przed-pandemicznej, pandemicznej i po-pandemicznej to świat dominacji ekonomii i globalnej gospodarki, kryzysu energetycznego, klimatycznego i ekologicznego oraz wirtualnej rzeczywistości i sztucznej inteligencji. W tym świecie, jak się może wydawać, sprawy kultury i dziedzictwa kulturowego, pamięci i tożsamości odeszły na plan dalszy, podlegają ciągłym dyskusjom i deklaracjom oraz poddawane są presji i dominacji celów tzw. wyższego rzędu. Przykładem w Europie dla powyższego może być mnogość Kart, Rezolucji, Konferencji - w różnych konfiguracjach - versus NextGenerationUE, Europiejski Zielony Ład, Europejska Fala Rewaloryzacji, a w tym tylko nieśmiało Europejski Nowy Bauhaus i Baukultur.

Rozważając, jak w dzisiejszych czasach należy odnieść się do trwałości wskazań i osiągnięć Karty Ateńskiej z 1931 roku oraz do intencji zapisów paryskiej Rekomendacji UNESCO w sprawie Historycznego Krajobrazu Miejskiego z 2011 roku i jej inkorporacji do naszych krajowych przepisów, należy zauważyć, że pojawiła się nowa inicjatywa. Jest to inicjatywa Nowego Europejskiego Bauhausu wyrosła $\mathrm{z}$ idei proekologicznego Europejskiego Zielonego Ładu i w ramach tzw. NextGenerationUE". Lansowana w Unii Europejskiej wraz z "Falą Renowacji". Ma wzmacniać wartości kulturowe dla realizacji polityki Baukultur przyjętej przez kraje Europy znanej, jako Deklaracja z Davos. W Polsce dla podjęcia współpracy w ramach Nowego Europejskiego Bauhausu powstała Polska Sieć Organizacji Architektonicznych. Zatem w kontekście tych nowych, pochodzących z aktywności lat 2018-2021, na problematykę doktryn, teorii, kart i rekomendacji, które dotychczas były głównymi kierunkowskazami w zakresie tego co przeszłe, teraźniejsze i ewentualnie przyszłe, trzeba spoglądać również i z takiej nowej perspektywy.

\section{Dokumenty doktrynalne}

W roku 2021 przypadają dwie istotne dla środowiska konserwatorskiego rocznice. Pierwsza to 90. lecie podpisania Karty Ateńskiej powstałej podczas międzynarodowej konferencji, która miała miejsce w dniach 21-30 października 1931 roku w Atenach ${ }^{2}$ i jest ciągle niezwykle aktualna ze swymi postanowieniami końcowymi. Nie należy jej mylić z uchwaloną przez CIAM Kartą Ateńską z 1933 roku³, odnoszącą się do zagadnień urbanistycznych. Druga to Rekomendacja UNESCO w Sprawie Historycznego Krajobrazu Miejskiego przyjęta na międzyrządowym spotkaniu ekspertów na temat historycznego krajobrazu miejskiego w Paryżu, w 27 maja 2011 roku (Rezolucja Nr 41 Konferencji Generalnej UNESCO, 10 listopada 2011r.) ${ }^{4}$.

${ }^{1}$ NextGenerationUE, https://europa.eu/next-generation-eu/index_pl.

${ }^{2}$ Karta Ateńska 1931, Vademecum Konserwatora Zabytków, Biuletyn ICOMOS, Warszawa 2000, ss. 11-14.

3 Karta Ateńska 1933, Uchwalona na IV. Kongresie CIAM w 1933 w Atenach dokument zawierający postulowane zasady nowoczesnego projektowania urbanistycznego. Została opublikowana w 1943. [za:] https://pl.wikipedia.org/wiki/Karta_Ate\%C5\%84ska_(1933); [dostęp: 27.12.2021].

4 HUL, Vademecum Konserwatora Zabytków, Międzynarodowe Normy Ochrony Dziedzictwa Kultury, Warszawa 2015, ss. 181-189. 


\section{1. Karta Ateńska z 1931r.}

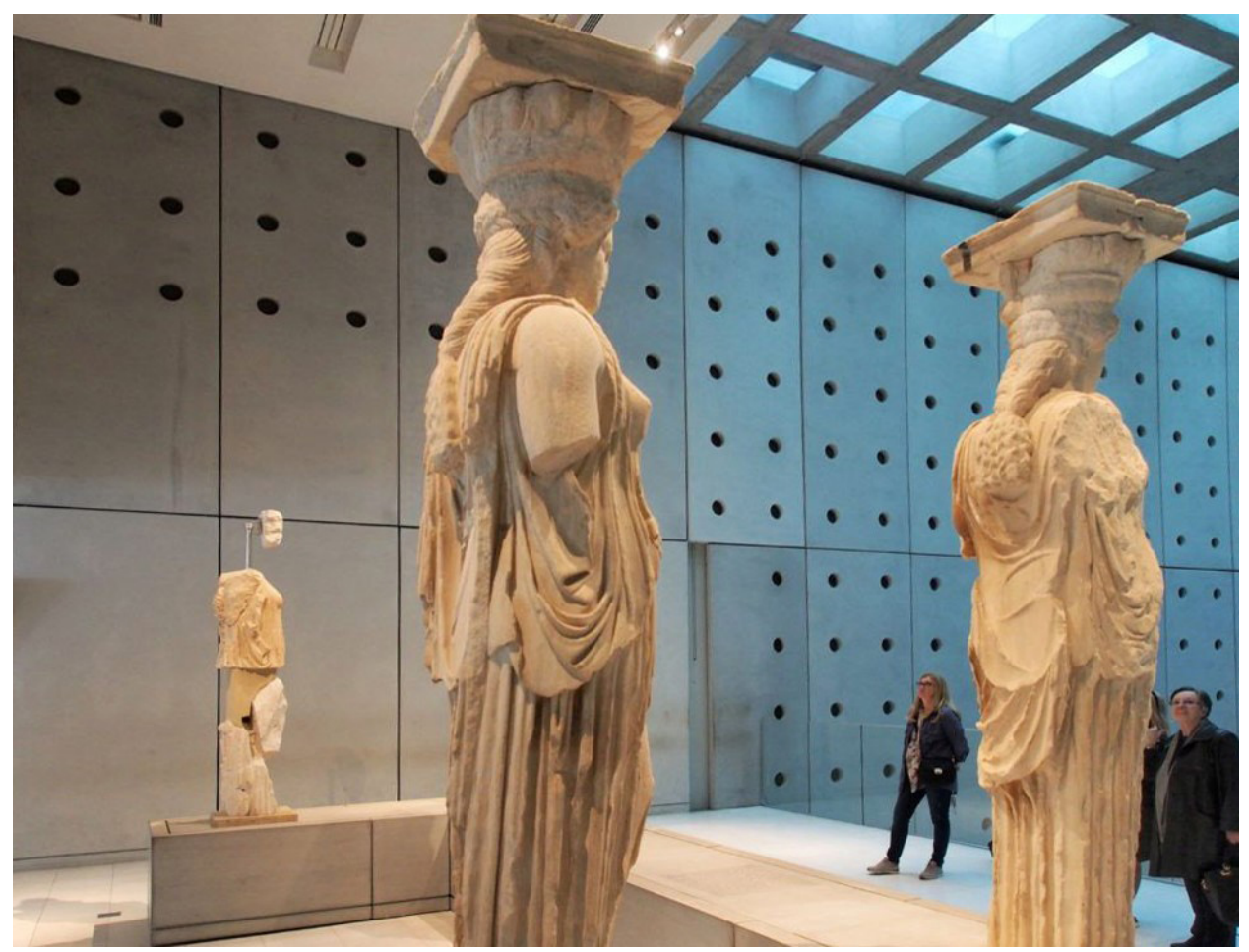

Ryc. 1 Muzeum Partenonu https://pedeka.pl/zwiedzanie-aten/

W postanowieniach konferencji w Atenach, zwołanej przez Międzynarodowe Biuro Muzeów 1931 roku, czyli w tzw. Karcie Ateńskiej przedstawiono konkluzje ogólne dotyczące spraw, które były przedmiotem obrad, w tym omawiano: doktryny i ich ogólne zasady, zarządzanie i ustawodawstwo dotyczące zabytków, uwypuklenie wartości zabytków, materiały stosowane do restauracji, zagrożenia zabytków, techniki konserwacji, współpracę międzynarodową $\mathrm{w}$ dziedzinie ochrony zabytków w tym w dziedzinie techniki i problemów etycznych oraz roli wychowania w poszanowaniu zabytków i przydatność dokumentacji międzynarodowej.

Główne problemy, intencje, zadania i zobowiązania zawarte Karcie Ateńskiej czyli tzw. karcie konserwatorskiej, w odróżnieniu od późniejszej Karty Ateńskiej z 1933 roku czyli tzw. karcie urbanistycznej, a wynikające z wymienionych wyżej konkluzji, to m.in.:

- unikanie pełnej restytucji i utrzymanie obiektów we właściwym stanie;

- respektowanie charakteru i fizjonomii dzieła historycznego i artystycznego bez wykluczeń epoki;

- współpraca z architektami;

- zapewnienie ciągłości istnienia i właściwej funkcji; 
- współpraca specjalistów i powszechna edukacja;

- studia przestrzeni i zachowanie oblicza miast, bez agresji elementów techniki i reklam;

- rozsądek wobec nowoczesnej techniki i ewentualnych zagrożeń;

- zainteresowania instytucji i państw zachowaniem zdobyczy cywilizacji i ich ochronę przed zagrożeniami;

- zagrożenie czynnikami atmosferycznymi;

- interes społeczny nad prywatnym i godzenie praw;

- zainteresowanie opinii na rzecz ochrony świadectw cywilizacji.

W Karcie Ateńskiej po raz pierwszy sformułowano ogólne zasady postępowania dotyczące zabytków i postawy konserwatorskiej, zalecane przez Ligę Narodów do stosowania we wszystkich krajach. W przeciągu minionych lat można zauważyć jak niewiele, w sprawach zasadniczych, zmieniło się $\mathrm{w}$ odniesieniu do dziedzictwa kulturowego i problematyki z nim związanej. Wiele wątków pozostaje nadal aktualnych i ciągle potrzebujących wsparcia ze strony instytucji państwowych i siły aktywności społecznej.

\section{2. Rekomendacja UNESCO w Sprawie historycznego krajobrazu miejskiego z 2011r. (Historic Urban Landscape Recommendation)}

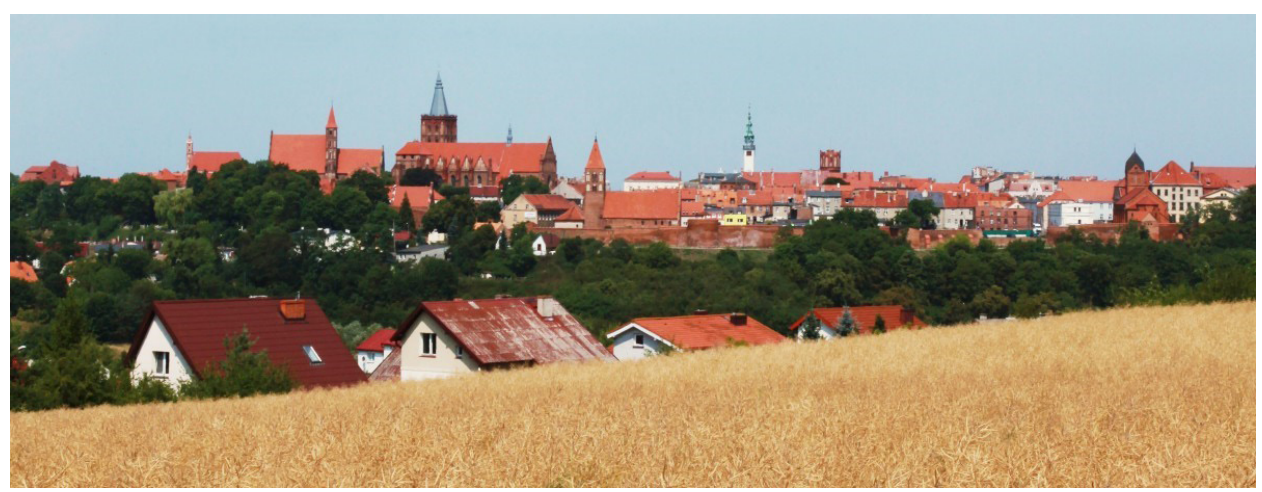

Ryc. 2 Panorama Chełmna, https://www.globtroter.pl/zdjecia/222981,polska,chelmno,pole,rzepakowe,panorama.html 
W preambule Rekomendacji zapisano m.in. delegację dla przyjęcia przez państwa członkowskie ram prawnych dla norm i zasad Rekomendacji. Zwrócono także uwagę na ewolucję koncepcji kultury i dziedzictwa oraz podejścia do zarządzania nimi. Główne intencje zapisów podjęto w uznaniu znaczenia podejścia krajobrazowego do historycznego dziedzictwa miejskiego, jako nowatorskiego sposobu ochrony dziedzictwa i zarządzania miastami historycznymi, $\mathrm{w}$ tym min. podkreślono:

- szerokie i zintegrowane podejście do waloryzacji i wartościowania historycznych krajobrazów miejskich w ramach zrównoważonego rozwoju;

- historyczny krajobraz kulturowy to również działania i wartości społeczne, kulturowe i ekonomiczne oraz dziedzictwo;

- znaczenie różnorodności kulturowej, tożsamości i kreatywności dla rozwoju społeczno-gospodarczego.

Po upływie 80. lat od Karty Ateńskiej najważniejsze różnice to nieco inny język, zakres i terminologia niż te użyte w Karcie, wynikające ze zmiany podejścia do dziedzictwa an bardziej kompleksowe oraz celów i upływu czasu to:

- urbanizacja i globalizacja; zrównoważone planowanie i projektowanie;

- rozwój i innowacyjne technologie budowlane, badania naukowe;

- ochrona środowiska miejskiego, urbanizacja i przystosowanie do zmian klimatycznych;

- dziedzictwo przyrodnicze i kulturowe jako zasoby zrównoważonego rozwoju;

- nowe funkcje, jako ważne inicjatywy gospodarcze;

- ochrona historycznych obszarów miejskich;

- charakter i integralność, standard i jakość życia;

- rozwijanie potencjału ludzkiego, włączenie społeczne;

- nadzór, zarządzanie dziedzictwem, finansowanie;

- interdyscyplinarność i współpraca;

W pewnym sensie, można jednak dostrzec w zapisach HUL, że ujęto tu częściowo postulatywność jednej i drugiej Karty Ateńskiej. Niemniej dokument ten wskazuje na znaczną ewolucję podejścia do dziedzictwa kulturowego i krajobrazowego, w tym materialnego i niematerialnego, architektury i urbanistyki, czyli dziedzictwa rozumianego całościowo. Pojawia się m.in. definicja historycznego krajobrazu miejskiego, odniesienie do zrównoważonego rozwoju oraz krajobraz kulturowy. Część Ustawy Krajobrazowej wykorzystała niektóre zapisy tej rekomendacji5 . Ponadto

5 Ustawa Krajobrazowa, https://sip.lex.pl/komentarze-i-publikacje/komentarze/ustawakrajobrazowa-komentarz-do-przepisow-wprowadzonych-w-587696001 [dostęp: 27.12.2021]. 
słownictwo Rekomendacji jest zbieżne ze słownictwem jakim posłużono się również w Nowym Europejskim Bauhausie i w Baukultur, o czym w kolejnym punkcie.

\section{3. Karta Lipska z 2007r. i Nowa Karta Lipska z 2020r.}

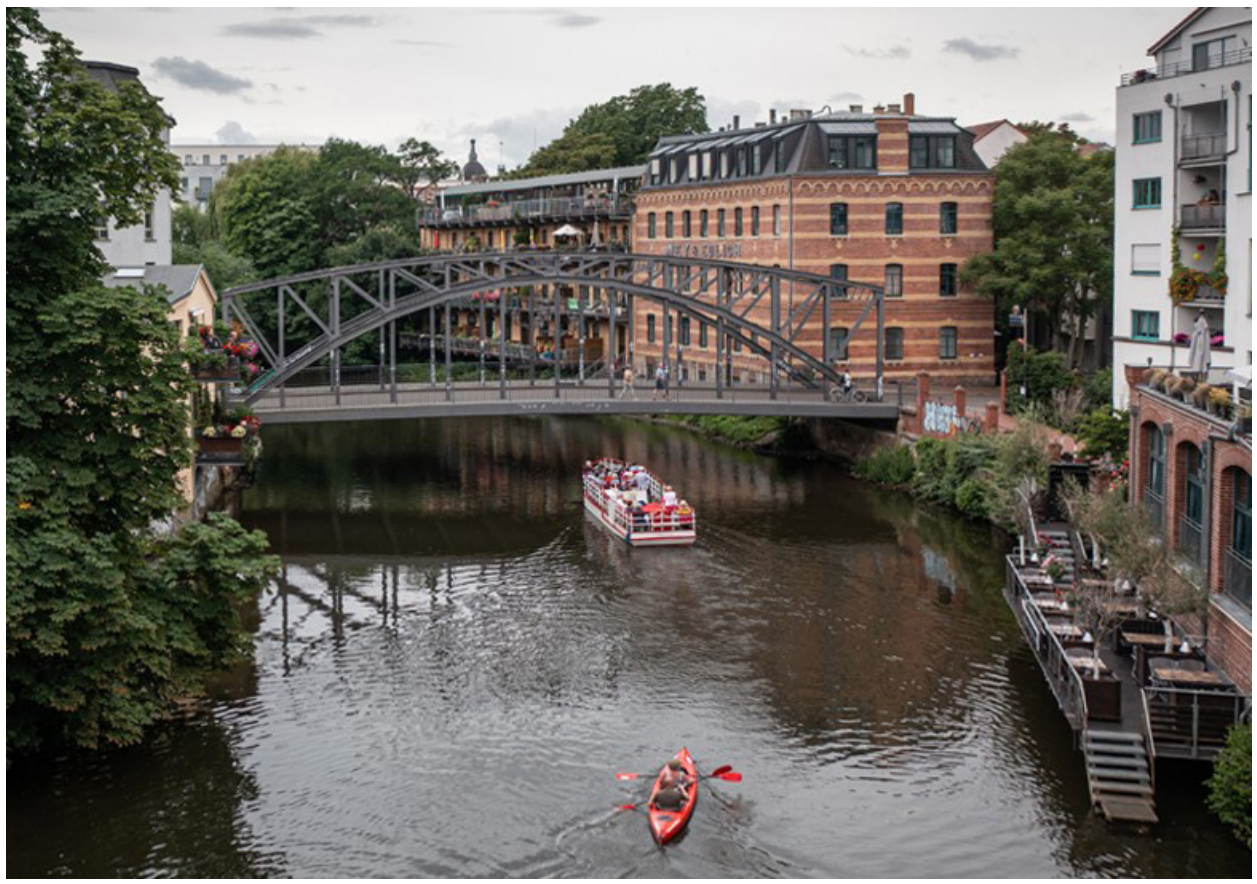

Ryc. 3 Lipsk, Könneritzbrücke nad rzeką - Biała Elstera https://kolemsietoczy.pl/lipsk-nowepojezierze-ciekawe-miejsca-trasy-co-zobaczycl

Dla dziedzictwa dotyczącego miast i ich okolic ważna jest Karta Lipska ${ }^{6} 2007$ roku i Nowa Karta Lipska $^{7}$ z 2020 roku. Zawarte w nich uzgodnienia, inicjatywy i zapisy związane są całościowo z obszarami miejskimi i z akcentowaniem zrównoważonego rozwoju i transformacji miast.

Pierwsza Karta Lipska „Na rzecz zrównoważonego rozwoju” jest efektem nieformalnego spotkania ministrów w sprawie rozwoju miast i spójności terytorialnej (Lipsk $24-25$ maja 2007r.). Nazywana jest Kartą na rzecz zrównoważonego rozwoju. Zapisano w niej min. działania takie jak:

- promowanie zintegrowanego rozwoju obszarów miejskich;

- aktywność na rzecz zrównoważonego rozwoju miast europejskich;

- wspólne zasady i strategie rozwoju miejskiego;

${ }^{6}$ Karta Lipska 2007, https://pl.wikipedia.org/wiki/Karta_Lipska_na_rzecz_ zr\%C3\%B3wnowa\%C5\%BConego_rozwoju_miast_europejskich [dostęp: 27.12.2021].

7 Nowa Karta Lipska 2020, https:// Nowa_Karta_Lipska\%20(2); [dostęp: 27.12.2021]. 
- dobrobyt gospodarczy, równowaga społeczna i zdrowe środowisko;

- tworzenie oraz ochrona funkcjonalnych i dobrze zaprojektowanych przestrzeni publicznych, infrastruktury i usług;

- dbałość o wartości kulturowe i architektoniczne dziedzictwo;

- zachowanie budynków historycznych, przestrzeni publicznych oraz ich wartości miejskiej i architektonicznej.

Nowa Karta Lipska „Transformacja siłą miast na rzecz wspólnego dobra”, zredagowana również na nieformalnym spotkaniu ministrów państw członkowskich UE ds. miejskich (Lipsk 30 listopada 2020r) jest aktualizacją poprzedniej Karty Lipskiej. Jest to „zbiór strategicznych zasad i kierunków dobrego zarządzania miastami, który określa politykę miejską w Europie po 2020 roku. Postulaty z pierwszej wersji dokumentu są nadal aktualne, natomiast Nowa Karta Lipska mocno podkreśla potrzebę transformacji w kierunku miast sprawiedliwych, zielonych i produktywnych."

Nowa Karta jest kartą transformacyjną, bardziej pro-energetyczną i pro-ekologiczną, a tyko nieznacznie skierowaną ku kulturze i ochronie dziedzictwa. Konsumuje, zatem nową tendencję skrystalizowaną w Europejskim Zielonym Ładzie, a tylko nieznacznie zwraca się w kierunku Baukultur. Dostrzeżona została także ważność trzech filarów transformacji: lepszego stanowienia prawa, lepszego finansowania i lepszej wiedzy koniecznych po pandemii Covid-19. Nowa Karta Lipska ukierunkowana jest szczególnie na sprawy Europy jako cywilizacji miejskiej. Zwrócono uwagę, że obecnie około 74\% ludności zamieszkuje w miastach i wiążą się z tym sprawy takie jak:

- konieczność zrównoważonej transformacji związana z globalizacją;

- kontekst zrównoważonych działań zintegrowanych i strategie rozwoju tworzone dla miasta jako całości ich siłą;

- potrzeba symbiozy miasta i obszarów sąsiednich;

- podejmowanie nowych inicjatyw europejskich, w zakresie kierunków rozwoju miast i ochrony dziedzictwa.

Karta ta zawiera dwa główne przesłania polityczne, którymi są takie działania jak zwrócenie szczególnej uwagi dla zdegradowanych dzielnic miast oraz dbałość o wysokiej jakości przestrzeń publiczną, zbudowaną w tym: zapewnienie i poprawa efektywności energetycznej, aktywna polityka innowacyjna i edukacyjna oraz tworzenie związków pomiędzy przemysłem, przedsiębiorcami i nauką.

8 Cytat: [za:] Nowa Karta Lipska 2020, https://www.gov.pl/web/fundusze-regiony/nowa-kartalipska-i-agenda-terytorialna-ue-2030-przyjete-przez-ministrow-krajow-wspolnoty-europejskiej [dostęp: 27.12.2021]. 


\section{Doktryny, a nowe aktywności - dzisiaj}

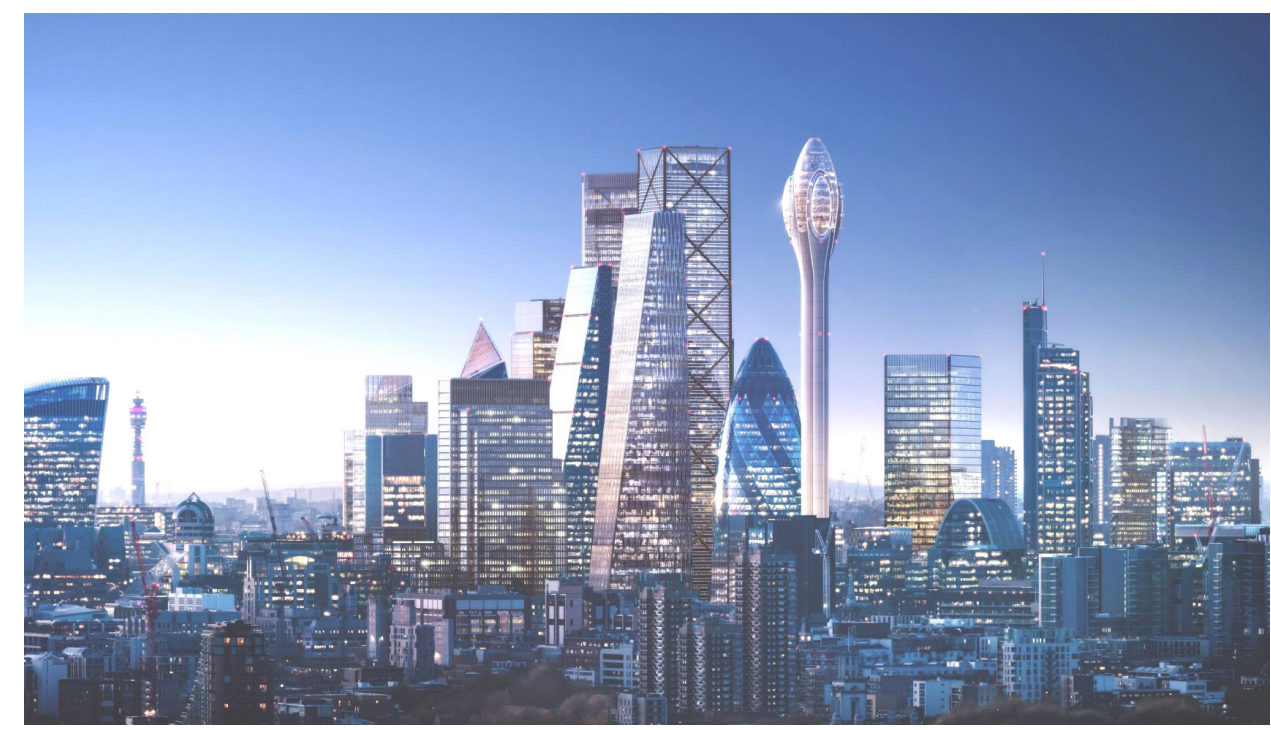

Ryc. 4 Panorama Londynu, https://www.bryla.pl/bryla/7,85298,24194252,londynski-tulipan-odfoster-partners.html

We współczesnym, dynamicznym i zglobalizowanym świecie obserwujemy dość często utratę znaczenia sztywnych doktryn, w miejsce których pojawiają się inicjatywy przynoszące nowe teorie, idee i priorytety mówiące również o zrównoważonym rozwoju i dobrej kontynuacji. Pojmowane są one przy tym nierzadko w sposób nieco odmienny niż miało to miejsce dotychczas, w środowisku związanym z zabytkowością i dziedzictwem kulturowym i krajobrazowym. Można by zatem zaryzykować jeszcze dyskusyjny pogląd, że mnogość i fragmentacja doktryn oraz różnych Kart i Konwencji konserwatorskich stała się ich naturalnym wrogiem.

Ważne przy tym w rozważaniach, przy teraźniejszym myśleniu o przyszłości ale w nowych uwarunkowaniach społeczno-politycznych, jest jednak zagadnienie poszanowania czasu przeszłego i pamięci, w tym pamięci kulturowej. Znaczenie mają także zagadnienia związane $\mathrm{z}$ interpretacją zakresu ważności prawa interesu prywatnego przy założeniu priorytetowego znaczenia interesu społecznego. Szczególnie w odniesieniu do konstytucyjnego uwarunkowania dla ochrony dziedzictwa kulturowego jako świadectwa narodu9. Nie można również pominąć problemu kultury budowania i działania $\mathrm{w}$ środowisku zbudowanym, ze szczególnym uwzględnieniem wagi krajobrazu kulturowego dla tożsamości i znaku czasu w przestrzeni, kultury w płynnej rzeczywistości ${ }^{10}$.

9 Problematyka ochrony dziedzictwa kulturowego, Konstytucja RP: art.5 - ochrona dziedzictwa narodowego, art.6 ust.2 - ochrona dziedzictwa kulturalnego, art.6 ust.1 i 73 w związku z art.31 ust.3 i art.64; [za:] Zalasińska K., [w:] Zalecenia dotyczace wdrożenia prawodawstwa UNESCO do polskiego porzadku prawnego, PK ds. UNESCO, Warszawa2013. (71).

${ }^{10}$ Bauman Z., Kultura w plynnej nowoczesności, Warszawa 2011. 
W tym kontekście na problematykę doktryn, teorii, kart i rekomendacji, które dotychczas były gównymi kierunkowskazami w zakresie tego co przeszłe, teraźniejsze i przyszłe trzeba spoglądać również z nowej perspektywy kryzysu ekonomicznego i klimatycznego oraz wynikających stąd zagrożeń. Rozważania skupiać się będą zatem w najbliższym czasie na tym, jakie przyjąć kierunki potrzebnej modyfikacji w podejściu do doktryn konserwatorskich, które są niezmienne od wielu lat i do takich, które powstały jako nowe, mające wpływ na te dotychczasowe. Również na tym, jak odnieść się cyfryzacji w konserwacji i ochronie zabytków, w dokumentacji dziedzictwa materialnego i niematerialnego oraz do nowych idei i priorytetów, w poszukiwaniu kompromisu dla ochrony dziedzictwa kulturowego. Szczególnie w dobie dominacji spraw dotyczących ochrony klimatycznej w Europie, jako priorytetu do 2025r.

Nowe aktywności w zakresie ochrony dziedzictwa związane są także z "oddolnym" ruchem społeczno-ekonomicznym i politycznym Nowego Europejskiego Bauhausu (2021), ale niestety nie koniecznie mającym wyraźnie odniesienie w strategii Europejskiego Zielonego Ładu (2019), w którym mało znalazło się miejsca dla idei Baukultur (2018), o czym w dalszej części. Wspomniane inicjatywy są jednak, w pewnym zakresie, bliskie zapisom konserwatorskiej Karty Ateńskiej (1931) i urbanistycznej Karty Ateńskiej (1933) oraz Nowej Karty Ateńskiej (1998) ${ }^{11}$ i Nowej Nowej Karty Ateńskiej (2003) ${ }^{12}$. Podobnie Karty Lipskiej (2007) i Nowej Karty Lipskiej (2020), a także intencji zapisów paryskiej Rekomendacji UNESCO w sprawie Historycznego Krajobrazu Miejskiego (2011). Dyskusja tym razem jednak być może będzie musiała toczyć się nie tylko $\mathrm{w}$ środowisku konserwatorskim ale również przy udziale nowych uczestników. Same daty pokazują, jak często w ostatnim okresie powstają nowe intencjonalne deklaracje, które jednak często nie mają umocowania w wiążących zapisach prawnych lub nie są implementowane do polskiego prawodawstwa.

${ }^{11}$ Biuletyn Informacyjny Towarzystwa Urbanistów Polskich, Numer Specjalny, Nowa Karta Ateńska 1998, Warszawa wrzesień 1998; [za:] Kłosek-Kozłowska D., Ochrona wartości kulturowych miast a urbanistyka, ss. 162-164.

${ }^{12}$ Towarzystwo Urbanistów Polskich, Nowa Karta Ateńska 2003, Wizja miast XXI wieku. 


\section{Deklaracja z Davos i idea Baukultur}

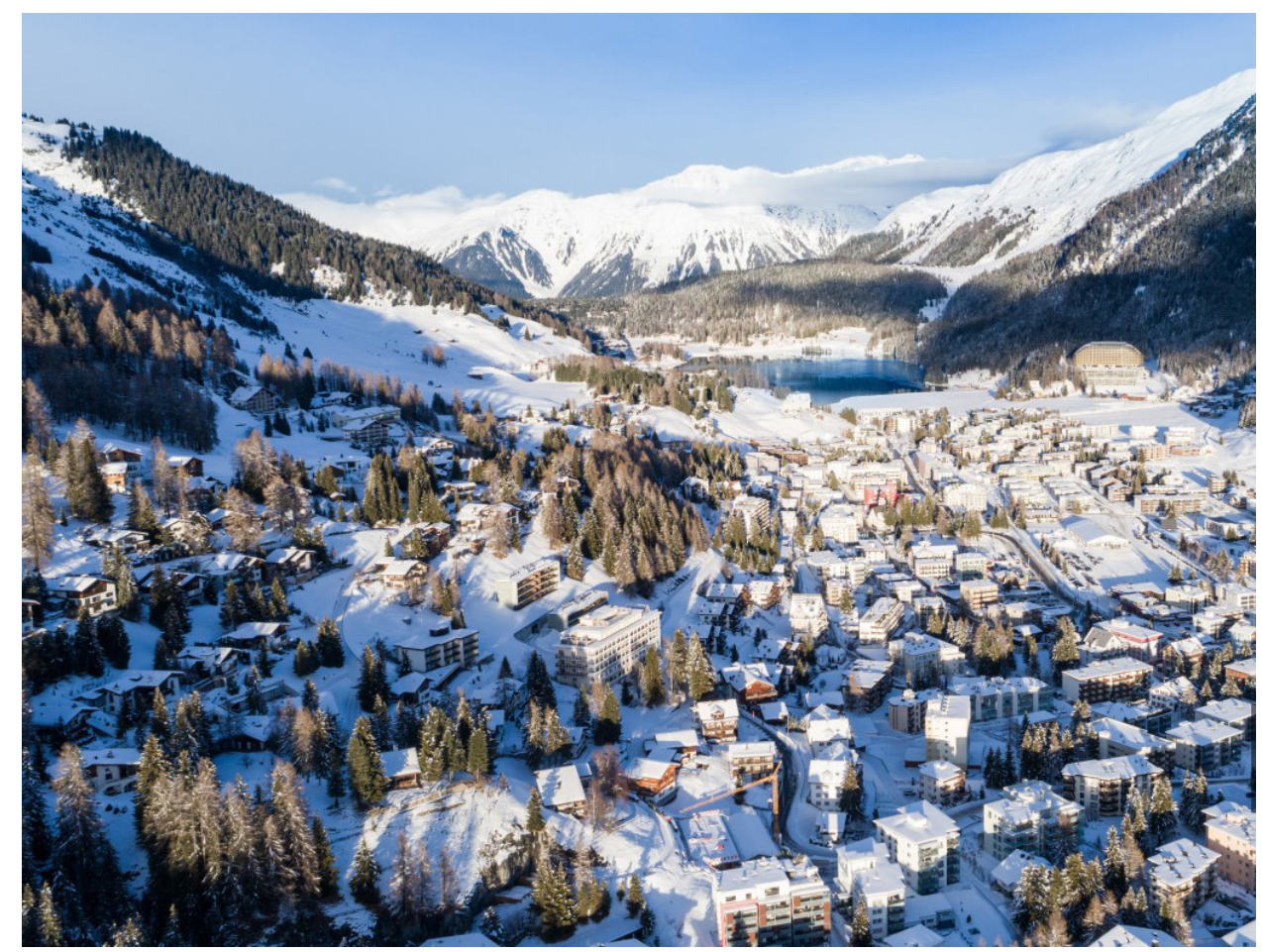

Ryc. 5 Panorama Davos, https://www.luftbilderschweiz.ch/luftaufnahmen/luftaufnahme-davospanorama/

Deklaracja z Davos „Ku wysokiej jakości Baukultur dla Europy” została podpisana na konferencji Ministrów Kultury z krajów Unii Europejskiej (Davos, Szwajcaria, 20-22 stycznia 2018 roku ${ }^{13}$. W jej Preambule zapisano min.: „My, Ministrowie Kultury i szefowie delegacji sygnatariuszy Europejskiej Konwencji Kulturalnej oraz państw-obserwatorów Rady Europy, a także przedstawiciele UNESCO, ICCROM-u, Rady Europy i Komisji Europejskiej oraz Rady Architektów Europy, Europejskiej Rady Planistów Przestrzennych, ICOMOS-u oraz Europa Nostra (...)":

- rozpatrując aktualne wyzwania, w tym trwałe skutki kryzysu gospodarczego i finansowego, czwartą rewolucję przemysłową, przyspieszoną urbanizację, kurczenie się regionów peryferyjnych, migracje i zmiany społeczne, rosnące nierówności, zmiany klimatyczne i szkody środowiskowe oraz ich znaczący wpływ na otoczenie w którym żyjemy;

${ }^{13}$ Deklaracja Z Davos; https://pap-mediaroom.pl/polityka-i-spoleczenstwo/mkidn-wicepremierpiotr-glinski-z-wizyta-w-davos-komunikat https:/niaiu.pl/wp-content/uploads/2021/09/ deklaracja_davos.pdf [dostęp: 27.12.2021]. 
- uznając istotny wkład wysokiej jakości przestrzeni zbudowanej w osiąganie zrównoważonego społeczeństwa (...)

- świadomi istotnych kroków, podjętych przez wspólnotę międzynarodową (...) oraz wypracowania nowego podejścia do ochrony i rozwoju wartości kulturowych europejskiej przestrzeni zabudowanej (...) tendencji do obniżenia jakości zarówno przestrzeni zbudowanych, jak i otwartych krajobrazów w całej Europie, widoczne w trywializacji prac budowlanych, braku wartości projektowych, obejmującym brak troski o zrównoważony rozwój, rosnącą eksurbanizację oraz nieodpowiedzialne użycie gruntów, degradację zabytkowej tkanki oraz utratę tradycji i tożsamości regionalnych (...)”.

W dalszej części Deklaracji zapisano zobowiązania dotyczące kultury, dziedzictwa i Baukultur, m.in. deklarację kluczowej roli kultury dla przestrzeni zbudowanej oraz zobowiązanie do wdrażania lepszej polityki, obejmującej skoncentrowaną na kulturze ideę Baukultur, a także uwzględniającej wizję wysokiej jakości Baukultur, jako kluczowego celu politycznego.

Koncepcja i wizja Baukultur, czyli szeroko rozumianej polityki Kultury Budowania (wybrane fragmenty):

- Baukultur obejmuje każdą działalność człowieka zmieniającą przestrzeń zbudowaną;

- Baukultur obejmuje istniejące budynki, zabytki i inne elementy dziedzictwa kulturowego, a także projekty i konstrukcje współczesnych budynków, infrastrukturę, przestrzeń publiczną i krajobrazy;

- Baukultur wyraża się również $\mathrm{W}$ procesach planowania przedsięwzięć budowlanych, infrastruktury, miast, wsi i otwartych krajobrazów;

- Dziedzictwo kulturowe jest nieodzownym komponentem wysokiej jakości Baukultur. Sposób w jaki używamy, utrzymujemy i chronimy nasze dziedzictwo kulturowe dziś, będzie kluczowy dla przyszłego rozwoju wysokiej jakości przestrzeni zbudowanej;

- Wysokiej jakości Baukultur wzmacnia poczucie przywiązania do miejsca (...). Tworzy przestrzeń zbudowaną, skupiając się na współczesnych formach wyrazu kulturowego (...) szanując kulturowe dziedzictwo (...) chroni środowisko (...) powiększa zieleń. 
Wysokiej jakości Baukultur, to, m.in.:

- balans między kulturowymi, społecznymi, gospodarczymi, środowiskowymi i technicznymi aspektami planowania, projektowania oraz budowy i adaptacji dóbr;

- część właściwych narzędzi prawnych; główny cel to wysoka jakość dla całej przestrzeni zbudowanej, w tym dziedzictwa kulturowego, we wszystkich działaniach o wpływie przestrzennym;

- kreatywne, funkcjonalne i społeczne aspekty; wszystkie istotne dyscypliny i specjaliści partycypują równych zasadach oraz wysiłki na polu edukacyjnym

- wszyscyzaangażowani, społeczeństwo isektor prywaty, ponosząodpowiedzialność za jakość przestrzeni zbudowanej przekazanej przyszłym pokoleniom;

- kultura umożliwia zrównoważony rozwój gospodarczy, społeczny i środowiskowy; kształtuje naszą tożsamość i określa nasze dziedzictwo; potrzeba całościowego, skoncentrowanego na kulturze podejścia do przestrzeni zabudowanej i pozostawionego przez nas dziedzictwa.

Idea Baukultur odnosi się do tego, że projektowanie i wznoszenie budynków i budowli jest kulturą i sztuką, a także tworzyć przestrzeń dla kultury. Przestrzeń zbudowana powinna być kształtowana $\mathrm{w}$ sposób zintegrowany, z uwzględnieniem wartości kulturowych. W myśl tej idei polityka powinna promować wysoką jakość planowania i projektowania, tak aby zapewnić właściwy balans pomiędzy oczekiwaniami społeczno-gospodarczymi, a zachowaniem zasobów i walorów dziedzictwa kulturowego, krajobrazowego i przyrodniczego.

W obecnie obowiązującym systemie prawnym w Polsce nie implementowano jak dotąd zapisów wynikających z Deklaracji w Davos oraz realizacji idei Baukultur. Widoczne to jest szczególnie w zmianach w dotychczasowym porządku związanych z wprowadzaniem idei Polskiego Ładu, ułatwieniom $\mathrm{w}$ budownictwie pozwalającym na daleko idącą swobodę $\mathrm{w}$ inwestowaniu bez dbałości o dziedzictwo krajobrazowe i dziedzictwo kulturowe, tak materialne ja i niematerialne, jak również swobodę kształtowania przestrzeni miast i obszarów pozamiejskich. Brak także Polskiej Polityki Architektonicznej, co powoduje że Polska jest jednym z nielicznych jeśli już nie jedynym krajem w Europie, który takiej nie posiada. 


\section{Nowy Europejski Bauhaus (New European Bauhaus. Beautiful/Sustaiable/Together)}

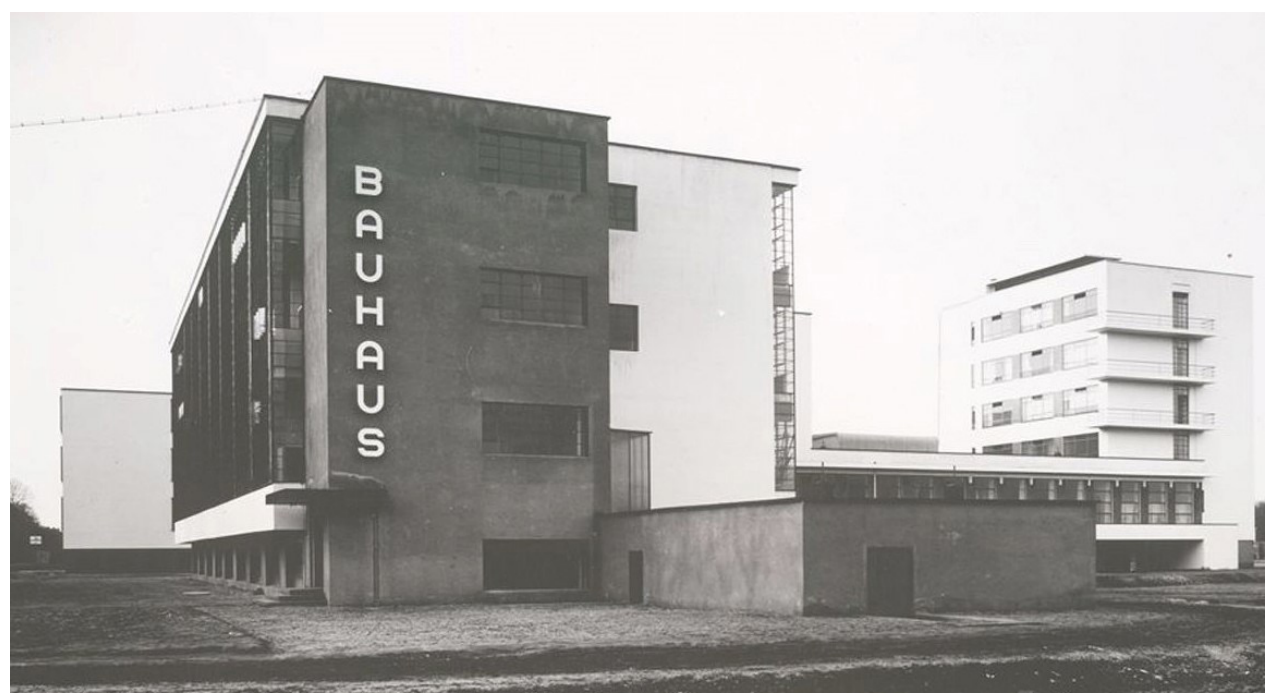

Ryc. 6 Budynek nowej szkoły Bauhausu, https://www.designalive.pl/bauhaus-nowaszkola/\#\&gid=1\&pid=2

Nowy Europejski Bauhaus (NEB) ${ }^{14}$ to europejska interdyscyplinarna inicjatywa podjęta przez kraje Wspólnoty Europejskiej w kontekście dbałości o dziedzictwo kulturowe. Wiąże się ona $z$ refleksją nad sposobem i możliwościami ochrony dziedzictwa materialnego i niematerialnego w zderzeniu z działaniami proekologicznymi i dążeniem do osiągnięcia neutralności klimatycznej w Europie do 2025 roku. Inicjatywa NEB zaistniała w 2020 roku w dużej mierze w niezależnie od międzynarodowego środowiska konserwatorskiego i wyrosła w oparciu o ideę proekologicznego Europejskiego Zielonego Ładu (EZŁ) oraz postawy państw europejskich dla kreacji polityki kulturalnej czyli BAUKULTUR. Przedstawiana jest przy tym jako pomost $\mathrm{z}$ ekologii i nauki do świata kultury i sztuki, z holistycznym podejściem do środowiska zbudowanego oraz jako praktyczna realizacja założeń EZŁ w przestrzeni mieszkalnej. Przewidziano trzy fazy wprowadzenia i rozwijania NEB:

I - projektowanie (2021), czyli tworzenie i rozwijanie pomysłów na transformacje miejsca w oparciu o wiedzę i zaangażowanie całej społeczności;

II - realizacja (2021-2024), czyli wspieranie władz miejskich, lokalnych i regionalnych we wspólnym projektowaniu i inkubacji projektów pilotażowych $\mathrm{w}$ różnych państwach członkowskich;

${ }^{14}$ Nowy Europejski Bauhaus, Z:A, nr 80; https://smart.gov.pl/pl/aktualnosci/129-nowy-europejskibauhaus; $\quad$ https://www.designalive.pl/przewodniczaca-komisi-europejskiej-oglasza-nowybauhaus/https://www.portalsamorzadowy.pl/fundusze-europejskie/nowy-europejski-bauhausodpowiedzia-na-obecne-i-przyszle-kryzysy,283771.html [dostęp: 27.12.2021]. 
III - rozpowszechnianie (od 2022 r.), czyli rozpowszechnianie pomysłów i rozwiązań NEB, zarówno w Unii Europejskiej, jak i poza nią.

Priorytetami dla NEB, we wszystkich wymienionych fazach są:

- zrównoważone: projektowanie, rozwój, przestrzeń pracy i odpoczynku, życie codzienne;

- inkluzyjność, wysoka jakość i estetyka;

- pomost: świat sztuki i kultury, a świat nauki i technologii;

- włączenie społeczne, interdyscyplinarność;

- kultura, dziedzictwo kulturowe, tożsamość kulturowa;

- przemodelowanie funkcjonowania miast, ulepszanie przestrzeni;

- połączenie zrównoważonego rozwoju, wysokiej jakości i estetyki;

- odpowiedź na obecne i przyszłe kryzysy społeczne i ekonomiczne;

- koewolucja, energooszczędność, ekologia.

Sama idea NEB rozwijana jest w ramach tzw. NextGenerationUE ${ }^{15}$ (NGUE), czyli unijnego funduszu odbudowy po pandemii wirusa COVID-19. NGUE ma na celu promowanie gospodarki neutralnej dla klimatu i dostosowania jej do zmieniającego się rynku pracy. Lansowana jest w ramach Unii Europejskiej wraz z "Falą Renowacji" (od 2021), która jednocześnie wprowadza nową taksonomię - nowe znaczenie pojęcia renowacji, w zetknięciu z działaniami na rzecz gospodarki o obiegu zamkniętym. W założeniu ma przy tym wzmacniać wartości kulturowe dla realizacji polityki Baukultur, przyjętej przez kraje Europy w 2018 roku jako Deklaracja z Davos.

\section{Europejski Zielony Lad (EZZ) i Europejska Fala Renowacji}

Europejski Zielony Lad (European Green Deal) ${ }^{16}$ to zbiór inicjatyw politycznych Komisji Europejskiej (KU), których nadrzędnym celem jest osiągnięcie neutralności dla klimatu w Europie do 2050. Komisja Europejska w roku 2019 określiła 10 priorytetów, zakładających dokonanie przeglądu każdego istniejącego prawa pod kątem jego wpływu na klimat, a także wprowadzenie nowych przepisów dotyczących gospodarki o obiegu zamkniętym, renowacji budynków, różnorodności biologicznej, rolnictwa i innowacji. Są nimi:

\footnotetext{
${ }^{15}$ NextGenerationUE: https://europa.eu/next-generation-eu/index_pl.

${ }^{16}$ Europejski Zielony Ead, https://pl.wikipedia.org/wiki/Europejski_Zielony_\%C5\%81ad\#searchInput; chrome-extension://efaidnbmnnnibpcajpcglclefindmkaj/viewer.html?pdfurl=https\%3A\%2F\%2Fdata. consilium.europa.eu\%2Fdoc\%2Fdocument\%2FST-13852-2020-INIT\%2Fpl\%2Fpdf\&clen=703857 [dostęp: 27.12.2021].
} 
- neutralność klimatyczna Europy;

- ekonomia o obiegu zamkniętym;

- renowacja budynków;

- zero zanieczyszczeń;

- ekosystemy i bioróżnorodność;

- zdrowa żywność i zrównoważone rolnictwo;

- zrównoważony transport;

- środki finansowe dla najbardziej potrzebujących regionów;

- badania, rozwój i innowacje;

- reprezentacja dyplomatyczna na zewnątrz UE.

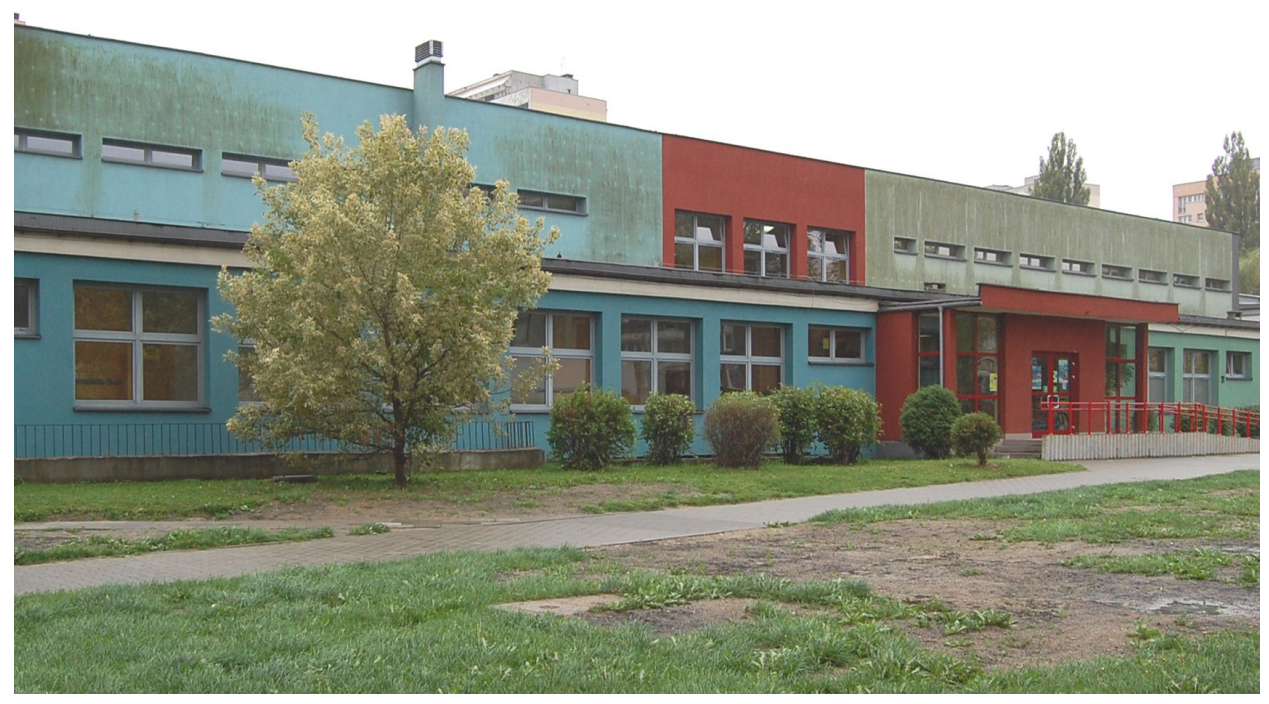

Ryc. 7 Szkoła podstawowa na osiedlu D3 w Tychach, po termorenowacji. Fot. Marcin Włodarczyk 2013

Realizacja neutralności klimatycznej w Europie do 2050 roku, jako głównego celu strategii EZŁ wymaga transformacji społeczno - gospodarczej w Europie postrzeganej jako racjonalna kosztowo, sprawiedliwa i zrównoważona społecznie. Niestety dziedzictwo kulturowe materialne i niematerialne, krajobraz kulturowy, zabytki, ochrona i opieka, krajobraz miejski, architektura i urbanistyka nie znalazły swojego miejsca w EZŁ i jego priorytetach. W związku z tym bezpośrednio lub pośrednio wynikają z tego konsekwencje i zagrożenia dla zabytków i dziedzictwa. Już widoczne dotyczą, między innymi: termoizolacji, fotowoltaiki, urządzeń klimatyzacji i teletechniki, urządzeń związanych z cyfryzacją i teletechniką, energii wiatrowej oraz oszczędności materiałowej i ekonomii zamkniętego obiegu. 
Europejska Fala Renowacji (EFR ${ }^{17}$ ) to również inicjatywa Komisji Europejskiej z 2020 roku, która jest kluczowym filarem dla realizacji Europejskiego Zielonego Ładu. Jest również priorytetem inicjatywy „Zielony Ład w terenie” oraz siłą zrównoważonego wzrostu i największym źródłem miejsc pracy. Dotyczy ona bowiem sektora związanego z budynkami już istniejącymi, jako sektora najbardziej energochłonnego. Rozumiana jest także, jako ich „ekologizacja”, tworzenie wspomnianych miejsc pracy z tym związanych oraz poprzez to działanie poprawę jakości życia i włączenie społeczne. Głównym celem „Fali Renowacji” jest usunięcie barier dla renowacji budynków takich jak:

- bariery strukturalne i bariery informacyjne;

- niedoskonałości rynku;

- brak wiedzy fachowej;

- utrudnienia dla projektów;

- bariery prawne.

Przyjęta przez Komisję strategia na rzecz „Fali Renowacji” ma objąć trzy obszary:

- dekarbonizacje ogrzewania i chłodzenia;

- zwalczanie problemu ubóstwa energetycznego i budynków o najgorszej charakterystyce;

- renowacje budynków publicznych tj. szkoły, szpitale i budynki administracyjne.

Podobnie jak w całej generalnej inicjatywie Europejskiego Zielonego Ładu także i w EFR nie ma mowy o renowacji zabytków, krajobrazu miejskiego, architektonicznego i urbanistycznego dziedzictwa kulturowego. Co może zdziałać „uwolniona” renowacja budynków widzimy na co dzień. Nie znamy odpowiedzi, a nawet propozycji, jak ma wyglądać renowacja dla zabytkowych obiektów. Podobnie jak zastosowanie w działaniu przy budynku lub budowli chronionej wytycznej tzw. obiegu zamkniętego.

$17 \quad$ Fala Renowacji: IP/20/1835, https://ec.europa.eu/commission/presscorner/detail/pl/ qanda_20_1836; https:/thinkco.pl/zielony-lad-fala-renowacji/https://cor.europa.eu/pl/news/Pages/ renovation-wave-CoR-and-Commission-launch-cooperation-to-boost-building-overhaul.aspx; [dostęp: 27.12.2021]. 


\section{Podsumowanie i inne konkluzje}

Polityka doktrynalna napotyka obecnie i najprawdopodobniej coraz częściej stykać się będzie ze zmiennymi oczekiwaniami zewnętrznymi związanymi z czynnikiem ludzkim i przyrodniczym. Sprowadza się to przykładowo do swobodnego odniesienia, niekoniecznie profesjonalnych w konserwatorstwie interesariuszy, do zabytkowości, presji działań ekonomicznych i ekologicznych oraz społecznych, jak również brakiem zrozumienia współczesnych trendów, nie tylko ekologicznych. Będzie musiała odnieść się do mnogości i fragmentacji dotychczasowych Deklaracji, Doktryn, Kart, Konwencji, Rekomendacji, itp., a także do nowych inicjatyw takich jak Baukultur i Nowy Europejski Bauhausu oraz Europejski Zielony Ład i najnowsza inicjatywa, czyli NexGenerationUE.

Polityka konserwatorska spotka się w przyszłości, jak można się w pewnym zakresie spodziewać, z podobnymi problemami zewnętrznymi jak polityka doktrynalna, $\mathrm{w}$ tym brakiem przeniesienia Deklaracji z Davos i idei Baukultur do polskiego prawodawstwa i towarzyszącym temu brakiem Polskiej Polityki Architektonicznej. Wymagać będzie to najprawdopodobniej elastycznego dostosowania ochrony zabytków i dziedzictwa kultury oraz opieki nad nimi nie tylko do ciągłej zmienności funkcjonalnej i technicznej, a także do nowych oczekiwań takich jak włączenie społeczne i zrównoważony rozwój gospodarczy oraz obieg zamknięty. Stanie przed trudnym zadaniem ochrony dziedzictwa krajobrazu kulturowego, materialnego i niematerialnego, architektoniczno-urbanistycznego i przyrodniczego, w dobie nacisków ekonomicznoekologicznych i deweloperskich. W tym także przygotowania do konsekwencji inicjatywy Europejskiego Zielonego Ładu i Polskiego Nowego Ładu oraz efektów działań związanych z Baukultur i Nowym Europejskim Bauhausem. Wydaje się zatem, że powinna być szerzej widoczna $\mathrm{w}$ prawodawstwie aby móc włączyć się $\mathrm{w}$ działania związane $\mathrm{z}$ oceną zadań, także w kontekście zapisów EZŁ, NEB i Baukultur.

W Polsce dla podjęcia współpracy w ramach NEB powstała już Polska Sieć Organizacji Architektonicznych, (PSOA), która w założeniu ma trwałość wartości i osiągnięć Karty Ateńskiej z 1931 roku, a także NEB i Baukultur oraz ich inkorporację do naszych krajowych przepisów. Przyjęła manifest POSA mówiący o zrównoważonym rozwoju, partycypacji społecznej, ochronie wartości kulturowych dziedzictwa i kryteriów estetycznych, a polityczna realizacji założeń doktrynalnych i rekomendacji związanych z ochroną zabytków i dziedzictwa kulturowego.

Nowy Europejski Bauhaus nawiązuje do idei Bauhausu, nie jest jednak stylem tylko multidyscyplinarnym działaniem łączącym m.in. projektowanie, kulturę, naukę, ekologię, społeczeństwo, ekonomikę i technologię dla współtworzenia przestrzeni oraz renowacji istniejącej substancji. Cytując: Nowy Europejski Bauhaus to projekt zwiazany z szukaniem sposobu na to, jak lepiej żyć po pandemii. To próba ukształtowania stylu projektowania zgodnie $z$ ideami zrównoważonego rozwoju, wprowadzenia założeń Europejskiego Zielonego Ładu do europejskich umysłów i domów, potrzeba wszystkich kreatywnych umystów: projektantów, artystów, naukowców, architektów i obywateli, aby Nowy Europejski Bauhaus odnióst sukces. (Ursula von der Leyen) ${ }^{18}$ (...)

${ }^{18}$ Cyt. za:https://sztuka-architektury.pl/article/14524/ [dostęp: 18.10.2021]. 
Aby go opracować w marcu 2021 roku został stworzony międzynarodowy zespót specjalistów. (...) To ci ludzie nie tylko opracują pomysly na rozwój Nowego Europejskiego Bauhausu, ale i stana się ambasadorami jego idei w Europie i na świecie."19 I tu powinno znaleźć się także miejsce dla aktywności i zaangażowania środowiska związanego z ochroną zabytków i krajobrazu kulturowego. Z duchem Nowego Europejskiego Bauhausu. Ale jak dotąd nie widzimy tego w priorytetach Europejskiego Zielonego Ładu.

Jak nigdy dotąd obserwujemy nacisk różnych grup i środowisk widzących tylko bieżące interesy i problemy bez dbałości o zastane i pozostawione trosce dziedzictwo, świadectwo kultury i tożsamości, pamięci przeszłości będącej budulcem i oparciem dla przyszłości. W starożytności mawiano: planować należy z myślą o siedmiu następnych pokoleniach. Obecnie mamy nie tylko kryzys ekonomiczny i klimatyczny. Mamy swego rodzaju kryzys kultury, może w kontekście globalizacji i bylejakości? A jak powszechnie wiadomo: zabierz narodowi jego świadectwa kultury, a przestanie istnieć. Jednocześnie, należy pamiętać, że we współczesnym dynamicznym świecie, sztywne trzymanie się pewnych doktryn traci na znaczeniu, takim jakie miało miejsce w minionym okresie. Ubolewać można, że przy okazji zwalczania kryzysu klimatycznego i energetycznego zapomina się często chociażby o nieszkodzeniu kulturze i dziedzictwu. Co ciekawe pierwsza data związana z niniejszą wypowiedzią to 1931 rok czyli Karta Ateńska, a ostatnia to 2021 rok czyli NextGenerationUE.

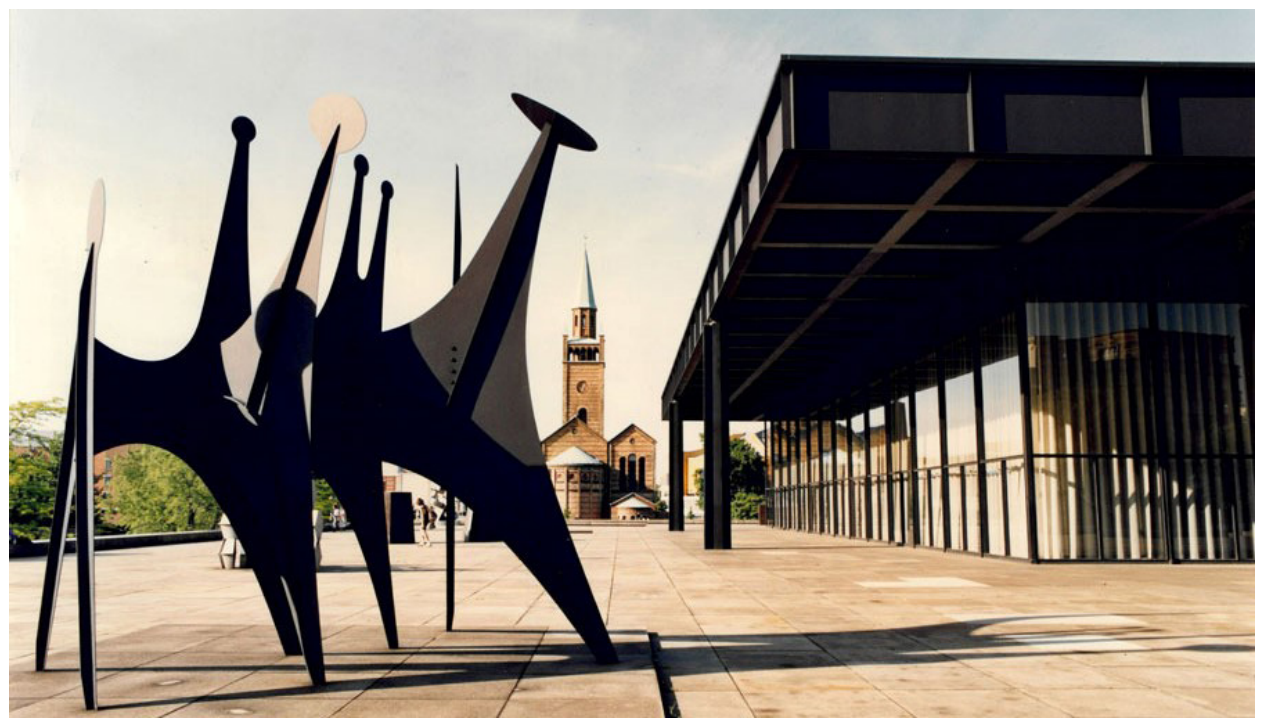

Ryc. 8 Rzeźba Aleksandra Caldera w Berlinie, https://www.archdaily.com/967467/mies-van-derrohes-neue-nationalgalerie-reopens-with-an-alexander-calder-exhibition/612732caf91c8194 5d000037-mies-van-der-rohes-neue-nationalgalerie-reopens-with-an-alexander-calder-exhibitionimage

${ }^{19}$ Ibidem. 


\section{Bibliografia}

Bauman Z., Kultura w plynnej nowoczesności, Warszawa 2011.

Biuletyn Informacyjny Towarzystwa Urbanistów Polskich, Numer Specjalny, Nowa Karta Ateńska 1998, Warszawa 1998.

Kłosek-Kozłowska D., Ochrona wartości kulturowych miast a urbanistyka, Warszawa, 2007.

Konstytucja RP, Warszawa 2013.

Rekomendacja UNESCO w sprawie historycznego krajobrazu miejskiego (2011), Warszawa 2013. Towarzystwo Urbanistów Polskich, Nowa Karta Ateńska 2003, Wizja miast XXI wieku.

Vademecum Konserwatora Zabytków, Biuletyn ICOMOS, Warszawa 2000.

Vademecum Konserwatora Zabytków, Międzynarodowe Normy Ochrony Dziedzictwa Kultury, Warszawa 2015.

Zalasińska, K., Zalecenia dotyczace wdrożenia prawodawstwa UNESCO do polskiego porządku prawnego, PK ds. UNESCO, Warszawa2013.

Zawód:Architekt, nr 80, Warszawa 2021 (022-026;028-034;036-042).

\section{Źródła internetowe}

Deklaracja $z$ Davos; https://pap-mediaroom.pl/polityka-i-spoleczenstwo/mkidn-wicepremierpiotr-glinski-z-wizyta-w-davos-komunikat deklaracja_davos.pdf [dostęp: 27.12.2021].

Europejski Zielony Lad, https://pl.wikipedia.org/wiki/Europejski_ Zielony_\%C5\%81ad\#searchInput; chrome, [dostęp: 27.12.2021].

Fala Renowacji: IP/20/1835, https://ec.europa.eu/commission/presscorner/detail/pl/ qanda_20_1836; [dostęp: 27.12.2021].

Karta Ateńska 1933, https://pl.wikipedia.org/wiki/Karta_Ate\%C5\%84ska_(1933); [dostęp: 27.12.2021].

Karta Lipska 2007, https://pl.wikipedia.org/wiki/Karta_Lipska_na_rzecz_ zr\%C3\%B3wnowa\%C5\%BConego_rozwoju_miast_europejskich [dostęp: 27.12.2021].

NextGenerationUE, https://europa.eu/next-generation-eu/index_pl., [dostęp: 27.12.2021].

Nowy Europejski Bauhaus, Z:A, nr 80; Warszawa 2020; https://smart.gov.pl/pl/aktualnosci/129nowy-europejski-bauhaus; [dostęp: 27.12.2021].

Nowa Karta Lipska 2020, https:// Nowa_Karta_Lipska\%20(2); [dostęp: 27.12.2021].

Ustawa Krajobrazowa, https://sip.lex.pl/komentarze-i-publikacje/komentarze/ustawakrajobrazowa-komentarz-do-przepisow-wprowadzonych-w-587696001 [dostęp: 27.12.2021]. 